\title{
Oxidized LDL Induces an Increase in the Relative Collagen Synthesis of Rabbit Aortic Smooth Muscle Cells
}

\author{
Shiro Jimi, Noriyuki Sakata, and Shigeo Takebayashi \\ The Second Department of Pathology, School of Medicine, Fukuoka University, Fukuoka, Japan.
}

\begin{abstract}
Cell degeneration and collagenosis are the main features in atherosclerotic plaque. We examined the effects of human low density lipoprotein (LDL) on cultured rabbit aortic smooth muscle cells (SMCs). Copper oxidized LDL (LDL $+C u$ ) injured the SMCs more than did native LDL. Cytotoxicity of oxidized LDL was prevented by the simultaneous addition of butylated hydroxytoluene (BHT) and ethylenediamine tetraacetic acid. Collagen synthesis increased up to 6 fold after incubation with $200 \mu \mathrm{g}$ protein $/ \mathrm{ml}$ of both native and oxidized LDL compared with that incubated in bovine serum albumin. Noncollagen protein synthesis was significantly reduced by oxidized LDL when compared to that by native LDL. Therefore, oxidized LDL increased the relative collagen synthesis $(3.33 \%)$ to a greater extent than did native $\mathrm{LDL}(0.72 \%)$. By adding $\mathrm{BHT}$ to $\mathrm{LDL}+\mathrm{Cu}$, the elevated relative collagen synthesis was reversed due to the restoration of noncollagen protein synthesis while it also inhibited LDL peroxidation as evaluated by the formation of malondialdehyde (MDA). However, sodium MDA (up to $200 \mu \mathrm{M}$ ) did not induce either cytotoxicity or an increase of relative collagen synthesis. We therefore conclude that oxidized human LDL enhanced the relative collagen synthesis coinciding with the induction of injury in cultured aortic SMCs, however free MDA may not be the component responsible for these effects. $J$ Atheroscler Thromb, 1994 ; 1 : $53-59$.
\end{abstract}

Key words : Collagen synthesis, Low density lipoprotein, Malondialdehyde, Lipid peroxidation, Smooth muscle cell

\footnotetext{
Atherosclerosis involves intimal thickening as a cellular response to a proliferation of smooth muscle cells (SMCs). Thereafter, collagenosis occurs in the deeper intima accompanied by the disappearance of SMCs. However, it is still unclear as to why the lesions become acellular and why SMCs suffer degenerative changes which often result in cell fragmentation or cell death in the fibrous plaque. It has been reported that arterial SMCs synthesize the components associated with the arterial extracellular matrix including collagen(1-3) elastin(1), and glycosaminoglycans $(1,4)$.

Hypercholesterolemia is believed to be one of the key factors for foam cell formation in atherosclerosis $(5,6)$.

Address for correspondence: Shigeo Takebayashi, M.D. and Ph.D., the 2nd Department of Pathology, School of Medicine, Fukuoka University, 45-1, Nanakuma 7-chome, Jonan-ku, Fukuoka 814-01, Japan.

Received August 3, 1993.

Accepted for publication September 28, 1993.
}

Since hypercholesterolemic or hyperlipoproteinemic serum contains many components other than low density lipoprotein (LDL), both positive and negative effects on collagen production in cultured cells have been reported $(7,8)$. However, ascorbic acid (9), estrogen (10), plateletderived growth factor (11), transforming growth factor (11) and dimethylsulphoxide-soluble particles from cigarette smoke (12) have been identified as stimulating factors for collagen synthesis in cultured cells.

Oxidized LDL can be generated by several kinds of cells such as endothelial cells (13), SMCs (14) and macrophages (15). Thus, one of the most plausible candidates for the presence of oxidized LDL in vivo is thought to be the arterial wall $(16,17)$. Oxidized LDL is recognized by the scavenger receptor of macrophages $(14,15,18,19)$ and SMCs (20), and leads to lipid accumulation in the cells. Oxidized LDL also has independent injurious or toxic properties that affect vascular SMCs (21). One cause of these LDL actions is supposed to be the lipid peroxidation 
in the LDL. Chojkier et al. (1989) (22) reported that following the addition of ascorbic acid, malondialdehyde (MDA), as a lipid peroxidation product, was formed in human fibroblasts, therefore MDA accumulation in the cells was an important step for subsequent collagen production.

In this study, we examined the relationship between collagen synthesis and cytotoxicity in rabbit aortic SMCs incubated with oxidized human LDL.

\section{Materials and Methods}

\section{Cell culture}

Aortic SMCs, derived from explants of the aortic media of New Zealand white rabbits, were grown at $37^{\circ} \mathrm{C}$ in Eagle's minimum essential medium (MEM) (SIGMA) containing $20 \%$ new born calf serum (SIGMA) in a humidified atmosphere of $95 \%$ air $/ 5 \% \mathrm{CO}_{2}$ as previously described (23). The SMCs used in this study were all in the fifth to seventh passage.

\section{LDL isolation and lipoprotein deficient serum}

LDL $(d=1.019-1.063 \mathrm{~g} / \mathrm{ml})$ was isolated from normal human plasma containing $1 \mathrm{mg} / \mathrm{ml}$ ethylenediamine tetraactic acid (EDTA) by ultracentrifugation according to the method described by Ferrei (24). Lipoprotein deficient serum (LPDS) $(\mathrm{d}=1.25 \mathrm{~g} / \mathrm{ml})$ was prepared by ultracentrifugation. LDL and LPDS were dialyzed against phosphate-buffered saline (PBS) containing 0.01\% EDTA at $4^{\circ} \mathrm{C}$ for 48 hours. Protein concentrations were determined by Lowry's method using bovine serum albumin as the standard.

\section{LDL oxidation and assay for thiobarbituric acid reacting substances}

LDL in PBS was oxidized by incubating LDL with $5 \mu \mathrm{M}$ $\mathrm{CuSO}_{4}$ for 24 hours at $37^{\circ} \mathrm{C}(18)$. The extent of lipid peroxidation in LDL was estimated by the amount of thiobarbituric acid reactive substances (TBARS)(25). LDL in MEM (50 $\mu \mathrm{g}$ protein in $500 \mu \mathrm{l}$ ) was mixed with 1.5 $\mathrm{ml}$ of $0.65 \%$ TBA and $20 \%$ trichloroacetic acid (TCA). After heating at $80^{\circ} \mathrm{C}$ for 1 hour, the reaction product was assayed fluorometrically using a Perkin-Elmer spectrofluorometer (model 650-10s), with excitation at $515 \mathrm{~nm}$ and emission at $553 \mathrm{~nm}$. Freshly diluted tetramethoxypropane was used as the standard. The results are expressed as nano moles TBARS/mg of LDL protein.

\section{Morphological examination}

Confluent SMCs in $18 \mathrm{~mm}$ culture dishes were incubated for 24 hours in MEM in the presence of $200 \mu \mathrm{g} \mathrm{BSA} /$ $\mathrm{ml}$ or LDL at a concentration of 100 or $200 \mu \mathrm{g}$ protein $/ \mathrm{ml}$. In some cases, $5 \mu \mathrm{M}$ copper ions were also added to the cultures. At the end of the incubation, the cells were gently rinsed with PBS, and then fixed with $1.4 \%$ buffered glutaraldehyde. SMCs were stained with $0.1 \%$ toluidine blue and examined by light microscopy.

\section{Collagen and protein synthesis}

SMCs were initially seeded at $5 \times 10^{4}$ cells/well in 24 well plates (Corning) and incubated in MEM containing $20 \%$ new born calf serum. After overnight incubation, the medium was changed to MEM containing 10\% LPDS. The cells were then incubated for 48 hours to eliminate any factors which could affect collagen and/or protein production. SMCs were then incubated for 24 hours in the presence of either $200 \mu \mathrm{g} \mathrm{BSA} / \mathrm{ml}, 200 \mu \mathrm{g} \mathrm{LDL} / \mathrm{ml}$ or $200 \mu \mathrm{g} \mathrm{LDL} / \mathrm{ml}$ plus $5 \mu \mathrm{M}$ copper ions. Alternatively, some cultures were incubated with $100 \mu \mathrm{M}$ or $200 \mu \mathrm{M}$ sodium malondialdehyde (MDA) prepared using the method described by Saslaw and Waravdekar (26). The medium also contained $0.1 \mathrm{M} \mathrm{L}$-ascorbic acid and $10 \mu \mathrm{Ci}$ / $\mathrm{ml}$ of $\left[5-{ }^{3} \mathrm{H}\right]$ proline $(35 \mathrm{Ci} / \mathrm{mmol})$ (Amersham). Collagen synthesis was determined by the method used by Webster and Harvey (27), with some modification for use with the $0.5 \mathrm{ml} /$ well culture medium in 24-well plates. Both the cellular and medial newly synthesized collagen, which were extracted overnight with $1 \mathrm{mg} / \mathrm{ml}$ pepsin containing 1 $\mathrm{M}$ acetic acid at $4^{\circ} \mathrm{C}$, were then purified by successive salt precipitations in acid and neutral $\mathrm{pH}$ at a concentration of 1.2 and $4.0 \mathrm{M} \mathrm{NaCl}$, respectively, using carrier collagen. To check for the purity of collagenous protein, the radiolabeled collagen was separated by electrophoresis on a sodium dodecyl sulphate-polyacrylamide gel containing $8 \%$ acrylamide (28). The extracted protein was fluorometrically identified and contained types I, III, IV and $\mathrm{V}$ collagens. Radiolabeled proline associated with those collagens was approximately $95 \%$ of the total by a densitometric analysis.

The measurement of noncollagen protein synthesis was performed as follows. After 24 hours of incubation with ${ }^{3} \mathrm{H}$-proline, both cellular and medial proteins were precipitated twice at $100^{\circ} \mathrm{C}$ by the addition of $10 \%$ TCA. The precipitated protein was then washed 4 times with TCA and was dissolved in $500 \mu \mathrm{l}$ of $1 \mathrm{~N} \mathrm{NaOH}$. The solution was neutralized with $1 \mathrm{~N} \mathrm{HCl}$ and was adjusted to a final volume of $1 \mathrm{ml}$. Noncollagen synthesis was calculated by subtracting the count for collagen from the count for total protein incorporated with proline. Relative collagen synthesis was also calculated using the formula proposed by Peterkofsky et al. (29) as follows : relative collagen synthesis =collagen synthesis/(noncollagen synthesis $\times 5.4+$ collagen synthesis).

\section{Dye exclusion assay}

A dye exclusion assay was performed to estimate the injurious effect of native and oxidized LDL on cells using $0.4 \%$ trypan blue solution (SIGMA). Dye accepting SMCs were counted under a light microscope and were expressed as a percentage of a total of 1,000 cells.

\section{DNA quantification and protein assay}

DNA in SMCs was extracted and quantified by the fluorometrical method(25) using Hoechst 33258 dye 
Table 1. LDL oxidation by copper ions and protective effect of antioxidants. LDL $(200 \mu \mathrm{g}$ protein $/ \mathrm{ml})$ in MEM was incubated with or without $5 \mu \mathrm{M} \mathrm{Cu}^{2+}$ for 24 hours in the presence of SMCs. Effects of antioxidants, BHT and EDTA were examined under several conditions.

\begin{tabular}{lcc}
\hline & $\begin{array}{c}\text { No added } \mathrm{Cu}^{2+} \\
\text { TBARS }(\mathrm{nM} / \mathrm{mg} \text { LDL protein) }\end{array}$ \\
\hline $\begin{array}{l}\text { LDL in MEM } \\
+ \text { BHT }(\mu \mathrm{m})\end{array}$ & 2.19 & 34.80 \\
50 & & \\
100 & & $2.63^{* *}$ \\
200 & 1.78 & $2.25^{* *}$ \\
+ EDTA $(\mu \mathrm{M})$ & & $2.31^{* *}$ \\
25 & & \\
50 & 2.47 & $15.35^{*}$ \\
\end{tabular}

All data are the mean of triplicate samples.

${ }^{*}: \mathrm{p}<0.05,{ }^{* *}: \mathrm{p}<0.01 \mathrm{vs} \mathrm{LDL}+\mathrm{Cu}^{2+}$

(American Hoechst, NJ) and thymus DNA (type 1) (SIGMA) as a standard. SMCs were harvested by trypsinization and washed with cold PBS. Cell pellets were digested in $0.1 \mathrm{~N} \mathrm{NaOH}$ and the protein contents in the cells were measured.

\section{Statistical analysis}

The data were examined by either Student's t test or Duncan's multiple range test.

\section{Results}

As shown in Table 1, the incubation of LDL at $37^{\circ} \mathrm{C}$ for 24 hours with $5 \mu \mathrm{M}$ copper ions resulted in extensive oxidation of LDL $(p<0.01)$. The values for TBARS increased more than fifteen fold when LDL was incubated with $5 \mu \mathrm{M}$ copper ions in the presence of SMCs (34.80 nM TBARS/mg LDL protein). However, the increase in TBARS was minimal when LDL was incubated in the absence of copper ion (2.19 nM TBARS/mg LDL protein). Two types of antioxidants were used, butylated hydroxytoluene (BHT) as a free radical scavenger and EDTA as a metal chelator. BHT effectively prevented the oxidation of LDL by copper ions. The concen tration of TBARS in the LDL incubated with 50,100 or $200 \mu \mathrm{M} \mathrm{BHT}$ was nearly the same in all cases, and were also comparable to the concentration in native LDL. EDTA also decreased the concentration of TBARS in LDL incubated with copper ions, but was less effective than BHT.

To check the cytotoxic effects of the different LDL conditions on SMCs, a trypan blue dye exclusion assay was used. Exposure to copper oxidized LDL resulted in the highest value for the dye accepting cells $(13.6 \%)$ as compared to that in the native LDL $(5.4 \%)(p<0.05$, Table 2). When antioxidants were added to the cultures in the
Table 2. Trypan blue exclusion assay on SMCs. The cytotoxic effects in various culture conditions are expressed as the percentage of injured SMCs accepting trypan blue dye.

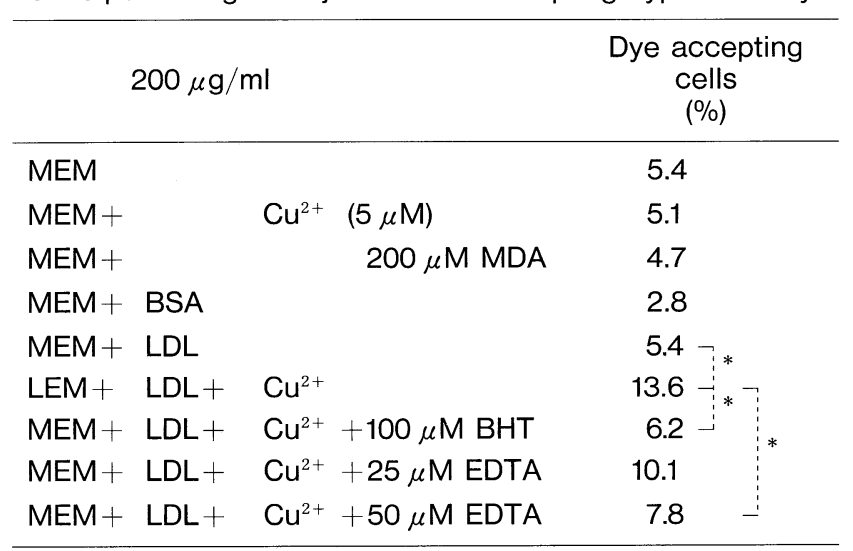

All data are the mean of triplicate samples.

* : $\mathrm{p}<0.05$

presence of LDL with copper, cytotoxic effects were prevented relative to the decrease in TBARS levels $(p<$ 0.05, Table 2).

In the cultures with $5 \mu \mathrm{M}$ copper ions and $200 \mu \mathrm{M}$ $\mathrm{BSA} / \mathrm{ml}$, there were no changes in cellular morphology after 24 hours of incubation. Light microscopy of the control cultures incubated in media without LDL showed confluent growth (Figs. 1A, B). The cultures with 100 or $200 \mu \mathrm{g} \mathrm{LDL} / \mathrm{ml}$ showed minimum changes, but still maintained either spindle or angular shapes (Figs. 1C, E). However, the same amount of LDL in the presence of copper ions induced cell damage in a dose-dependent manner (Figs.1D, F). The cells condensed with a shrunken cytoplasm and were rounded.

The protein concentration in cells incubated with copper oxidized LDL was significantly lower than that in the cells with either BSA or LDL alone (Table 3). However, no statistical differences were observed in the DNA contents of the cells incubated with $200 \mu \mathrm{g} \mathrm{BSA} / \mathrm{ml}, 200$ $\mu \mathrm{g} \mathrm{LDL} / \mathrm{ml}$ or $200 \mu \mathrm{g} \mathrm{LDL} / \mathrm{ml}$ with $5 \mu \mathrm{M}$ copper ions.

Collagen synthesis by SMCs after 24-hours incubation is shown in Table 4. No differences in collagen production were observed for incubation in MEM only, or after adding $5 \mu \mathrm{M}$ copper ions and $200 \mu \mathrm{g} \mathrm{BSA} / \mathrm{ml}(0.78,0.85$, $1.56 \times 10^{3} \mathrm{cpm} / \mathrm{ng} \mathrm{DNA}$, respectively). When cells were incubated with $200 \mu \mathrm{g} \mathrm{LDL} / \mathrm{ml}$, the collagen production was dramatically increased ( 7 fold) over that of cells in BSA ( $p<0.01)$. In addition, copper oxidized LDL induced almost the same degree of collagen production as native LDL.

Table 4 shows the noncollagen protein synthesis in SMCs. The level of noncollagen protein synthesis in native LDL was similar to that of the BSA control. However, by incubating LDL with copper ions the noncollagen protein synthesis declined substantially $(p<$ 0.01). When relative collagen synthesis was adopted 

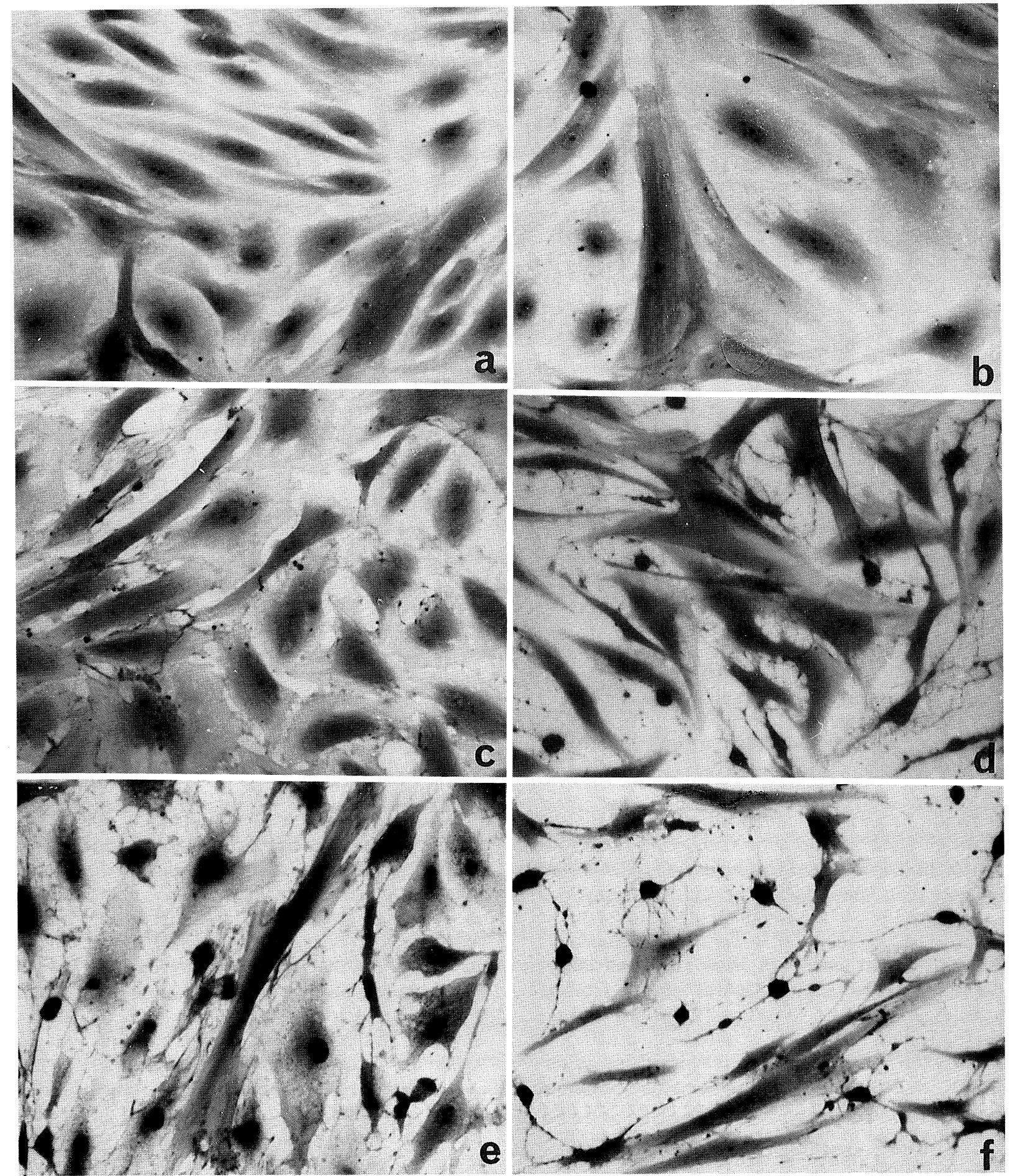

Fig. 1. Rabbit aortic SMCs were incubated for 24 hours in the presence of $200 \mu \mathrm{g} / \mathrm{ml} \mathrm{BSA}$ (a, b), $100 \mu \mathrm{g} / \mathrm{ml}$ LDL (c, d) or $200 \mu \mathrm{g} / \mathrm{ml}$ LDL (e, f). The cultures shown in b, $\mathrm{d}$ and $\mathrm{f}$ contained $5 \mu \mathrm{M}$ copper ions. The cells were fixed with $1.4 \%$ buffered gluteraldehyde and stained with $0.1 \%$ toluidine blue. 
Table 3. DNA and protein contents in SMCs. After SMCs were incubated with $200 \mu \mathrm{g} / \mathrm{ml}$ BSA, native LDL and copper oxdized LDL, DNA and protein contents of SMCs were measured.

\begin{tabular}{lccc}
\hline $200 \mu \mathrm{g} / \mathrm{ml}$ & $\mathrm{ng}$ DNA/well & $\mu \mathrm{g}$ protein/well & $\begin{array}{c}\text { Protein/DNA } \\
(\mathrm{ng} / \mathrm{ng})\end{array}$ \\
\hline $\mathrm{BSA}$ & $359.8 \pm 115.6$ & $86.2 \pm 1.4$ & 239.6 \\
$\mathrm{LDL}$ & $373.3 \pm 65.7$ & $94.7 \pm 3.3$ & 253.7 \\
$\mathrm{LDL}+\mathrm{Cu}^{2+}$ & $319.8 \pm 46.3$ & $63.4 \pm 5.6$ & 198.2 \\
\hline
\end{tabular}

mean $\pm S D(n=3)^{*}: p<0.05,^{* *}: p<0.01,{ }^{* * *}: p<0.001$

Table 4. Noncollagen protein and collagen synthesis in SMCs. SMCs were incubated with the indicated agents in MEM for 24 hours, and noncollagen and collagen synthesis were measured as described in the text.

\begin{tabular}{lccc}
\hline $200 \mu \mathrm{g} / \mathrm{ml}$ & $\begin{array}{c}\text { Noncollagen } \\
\text { protein } \\
\text { synthesis } \\
\left(\times 10^{3} \mathrm{cpm} / \mathrm{ng} \text { DNA }\right)\end{array}$ & $\begin{array}{c}\text { Collagen } \\
\text { synthesis } \\
(10 \mathrm{cmp} / \mathrm{ng} \text { DNA })\end{array}$ & $\begin{array}{c}\text { Relative } \\
\text { collagen } \\
\text { synthesis } \\
(\%)\end{array}$ \\
\hline (MEM only $)$ & $1.97 \pm 0.08$ & $0.78 \pm 0.11$ & 0.07 \\
$\mathrm{BSA}$ & $2.26 \pm 0.13$ & $1.56 \pm 0.45-*$ & 0.13 \\
$\mathrm{LDL}$ & $2.79 \pm 0.28-$ & $11.00 \pm 0.13-*$ & 0.72 \\
$\mathrm{LDL}+\mathrm{Cu}$ & $0.60 \pm 0.04-*$ & $11.14 \pm 2.43$ & 3.33 \\
$\mathrm{LDL}+\mathrm{Cu}+100 \mu \mathrm{M}$ BHT & $2.35 \pm 0.11$ & $9.69 \pm 0.34$ & 0.76 \\
$\mathrm{LDL}+\mathrm{Cu}+25 \mu \mathrm{M}$ EDTA & - & $10.88 \pm 0.43$ & - \\
$\mathrm{LDL}+\mathrm{Cu}+50 \mu \mathrm{M}$ EDTA & - & $10.07 \pm 1.03$ & - \\
\hline
\end{tabular}

$\mathrm{Cu}: 5 \mu \mathrm{M} \mathrm{Cu}^{2+}$, mean $\pm \mathrm{SD}(\mathrm{n}=3),{ }^{*}: \mathrm{p}<0.01$

Table 5. Effects of MDA on noncollagen protein and collagen synthesis in SMCs. After sodium MDA was added to the SMC cultures, noncollagen and collagen synthesis in a 24 hour incubation were measured as described in the text.

\begin{tabular}{lccc}
\hline & $\begin{array}{c}\text { Noncollagen protein } \\
\text { synthesis } \\
\left(\times 10^{3} \mathrm{cpm} / \mathrm{ng} \text { DNA }\right)\end{array}$ & $\begin{array}{c}\text { Collagen } \\
\text { synthesis } \\
(\times 10 \mathrm{cpm} / \mathrm{ng} \text { DNA })\end{array}$ & $\begin{array}{c}\text { Relative } \\
\text { collagen } \\
\text { synthesis } \\
(\%)\end{array}$ \\
\hline $\mathrm{MEM}$ & $1.97 \pm 0.07$ & $0.78 \pm 0.11$ & 0.07 \\
$\mathrm{MEM}+100 \mu \mathrm{M}$ MDA & - & $0.70 \pm 0.19$ & - \\
$\mathrm{MEM}+200 \mu \mathrm{M}$ MDA & $1.66 \pm 0.07$ & $0.89 \pm 0.11$ & 0.10 \\
\hline
\end{tabular}

mean $\pm S D(n=3)$

instead of collagen synthesis, copper oxidized LDL induced a more than 4 fold higher value (3.33\%) than native LDL $(0.72 \%)$ or BSA alone $(0.13 \%)$. BHT $(100 \mu \mathrm{M})$ was then added to the media containing LDL and copper ions. There were no differences in collagen synthesis when compared to the native or copper oxidized LDL, however due to the restoration of noncollagen protein synthesis by $\mathrm{BHT}$, the relative collagen synthesis decreased by $0.76 \%$ which was comparable to that in native LDL.

We also studied the effects of MDA on SMCs. There were no differences detected in the dye exclusion assay when SMCs were incubated with media containing either MEM alone or $200 \mu \mathrm{M}$ MDA for 24 hours (Table 2). No changes in either collagen or relative collagen synthesis by those cells were observed.

\section{Discussion}

It has been belived that hyperlipidemic serum carries more oxidation products than normolipidemic serum (30). The role of oxidized LDL in atherogenesis has been receiving increased attention $(6,17,18)$. However, one study claims that the oxidation product, MDA, stimulates collagen synthesis in vitro (22). There has been no prior report examining the stimulatory effect of oxidized LDL on collagen synthesis. 
Oxidized LDL has been shown to be injurious or cytotoxic to several kinds of cells including SMCs (21). In this study, both native and oxidized LDL caused morphological damage in the cultured SMCs. However, the effects of the oxidized LDL were consistently more extensive. This was also supported by a dye exclusion assay which indicated a stronger cytotoxicity for oxidized LDL. The possibility must also be considered that some changes caused by the native LDL were due to the oxidation effects resulting from the interaction between the cell and LDL after LDL had been endocytosed.

Noncollagen protein synthesis in SMCs incubated with copper oxidized LDL showed a significant decrease (21\% of the control), which resulted in a decreased total protein content $(67 \%$ of the native LDL). The reduction in noncollagen protein synthesis was not likely due to a shifting of the substrate to collagen synthesis since both the native and oxidized LDL treated SMCs increased collagen synthesis, however, only the oxidized LDL-treated SMCs had greatly reduced noncollagen protein synthesis.

Chojkier et al. (22) reported that ascorbic acid induced lipid peroxidation-stimulated collagen production in cultured human fibroblasts. Collagen synthesis in these cells was also elevated by the direct addition of $200 \mu \mathrm{M}$ MDA as a peroxidation end product. They thus concluded that the formation of aldehyde in the cells was necessary for the stimulation of collagen gene expression. In our study, both native and oxidized LDL stimulated collagen production more strongly as compared with the BSA control, while no such difference was found between the LDLs. When MDA, which had a maximum concentration $(200 \mu \mathrm{M}) 28.7$ fold higher than that in the oxidized LDL, was directly added to the cultures, no effect such as oxidized LDL, was noted on either collagen synthesis or cytotoxicity in the rabbit aortic SMCs. Thus, it appears that either peroxidation or the peroxidation products carried in LDL, other than free MDA, are involved in the subsequent cytotoxicity and depression of noncollagen protein synthesis in SMCs. However, the exact causes of these differences, especially regarding MDA, could not be defined.

When relative collagen synthesis was adopted, in contrast to total protein synthesis, the oxidized LDL induced an increase in the relative collagen synthesis $(3.32 \%)$ as compared with that of native LDL $(0.70 \%)$. This increase was reversed by the addition of BHT accompanied by the prevention of cytotoxicity. A reciprocal effect has also been reported for cigarette smoke which is also known to be a risk factor for atherosclerosis. A component of cigarette smorke extracted by dimethylsulphoxide increased both collagen synthesis and cytotoxicity in SMCs (12). These actions were also reversed by the addition of protease inhibitors. Therefore, the toxic components in the blood caused cell degeneration, and the injured SMCs thus responded by increasing collagen production. An accumulation of oxidized LDL has been demonstrated in advanced fibrous plaque in humans and rabbits $(17,31)$. There are two distinct characteristics of this plaque, one is the substantial accumulation of the extracellular matrix (1-3), while the other is tissue necrosis where fragmented and dying SMCs are present (32). Either endogenous or exogenous regulatory mechanisms on SMCs must be involved to become acellular in the advanced collagenous plaque. Our results suggest that oxidized LDL is a component which allows for these two major changes seen in atherosclerotic plaque. Therefore, oxidized LDL might play a role in the formation of not only lipid-laden foam cells, but also advanced stages of atherosclerosis by causing both collagenosis and cell degeneration.

\section{References}

(1) Oakes BW, Batty AC, Handley CJ, and Sandberg LB: The synthesis of elastin, collagen, and glycosaminoglycans by high density primary cultures of neonatal rat aortic smooth muscle. An ultrastructural and biochemical study. Eur J Cell Biol, 27 : 34-46, 1982

(2) Mayne R: Collagenous proteins of blood vessels. Arterioscle rosis, $6: 585-593,1986$

(3) Ooshima A: Collagen $\beta$ chain: Increased proportion in human atherosclerosis. Science, 213: 666-668, 1981

(4) Bertelsen S: Chemical studies on the arterial wall in relation to atherosclerosis. Ann NY Acad Sci, 149: 643-654, 1958

(5) Goldstein JL and Brown MS : Binding and degradation of low density lipoprotein by cultured human fibroblasts. J Biol Chem, 249: 5153-5162, 1974

(6) Aviram M: Modified forms of low density lipoprotein and atherosclerosis. Atherosclerosis, 98: 1-9, 1993

(7) St Clair RW, Jones DC, and Hester SH : Failure of hypercho lesterolemic serum to stimulate collagen synthesis in aortic smooth muscle cells from two species of primates having different rate of collagen synthesis. Proc Soc Exp Biol Med, 174 : 137-142,1983

(8) Holderbaum D, Earhart LA, and Mccllagh KG: Effects of hyper lipoproteinemic serum and exogenous proline concentration on collagen synthesis by isolated rabbit aortas. Proc Soc Exp Biol Med, 150: 363-367, 1975

(9) Lyons BL and Schwartz RL: Ascobate stimulation of PAT cells causes an increase in transcription rates and decrease in degeneration rates of procollagen in RNA. Nuc Acids Res, 12 : 2569-2579, 1984

(10) Beldekas JC, Gerstenfeld L, Sonenshein GE, and Franzblau C : Cell density and estradiol modulation of procollagen type III in cultured calf smooth muscle cells. J Biol Chem, 257 : 12252-12256, 1982

(11) Amento EP, Ehsani N, and Palmer HL: Cytokines and growth factors positively and negatively regulate interstitial collagen gene expression in human vascular smooth muscle cells. Arterioscler and Thromb, 11: 1223-1230, 1991

(12) Stavenow $L$ : Stimulation of collagen secretion by factors released from injured arterial smooth muscle cells in culture. Atherosclerosis, 59: 187-197, 1986

(13) Henriksen T, Mahoney EM, and Steinberg D: Enhanced macrophage degradation of low density lipoprotein previ- 
ously incubated with cultured endothelial cells : Recognition by receptors for acetylated low density lipoprotein. Proc Natl Acad Sci USA, 78: 6499-6503, 1981

(14) Henriksen T, Mahoney EM, and Steinberg D: Enhanced macrophage degradation of biologically modified low density lipoprotein. Arteriosclerosis, 3: 149-159, 1983

(15) Parthasarathy S, Printz DJ, Boyd D, Joy L, and Steinberg $D$ : Macrophage oxidation of low density lipoprotein generates a modified from recognized by scavenger receptor. Arteriosclerosis, $6: 505-510,1986$

(16) Steinberg D, Parthasarathy S, Carew TE, Khoo JC, and Witztum $\mathrm{JL}$ : Modifications of low-density lipoprotein that increase its atherogenicity. N Engl J Med, 302: 915-924, 1989

(17) Yla-herttuala S, Palinski W, Rosenfeld ME, Parthasarathy S, Carew TE, Butler S, Witzum JL, and Steinberg D Evidence for the presence of oxidatively modified LDL in atherosclerotic lesions of rabbit and man. $\mathrm{J}$ Clin Invest, 84: 1086-1095, 1989

(18) Parthasarathy S, Steinbrecher UP, Barnett J, Witztum JL, and Steinberg D: Oxidatively modified low density lipoprotein: A potential role in recruitment and retention of monocyte/macrophages during atherogenesis. Proc Natl Acad Sci USA, 82 : 3000-3004, 1987

(19) Sparrow CP, Parthasarathy S, and Steinberg D: A macrophage receptor that recognizes oxidized low density lipoprotein but not acetylated low density lipoprotein. J Biol Chem, 264 : 2599-2604, 1989

(20) Dejager S, Mietus-Snyder M, and Pitas RE : Oxidized low density lipoproteins bind to the scavenger receptor expressed by rabbit smooth muscle cells and macrophages. Arterioscler and thromb, 13:371-378, 1993

(21) Morel DW, Hessler JR, and Chisolm GM : Low density lipoprotein cytotoxicity induced by free radical peroxidation of lipid. J Lipid Res, 24 : 1070-1076, 1983

(22) Chojkier M, Houglum K, Solis-Herruzo J, and Brenner DA : Stimulation of collagen gene expression by ascorbic acid in cultured human fibroblast. J Biol Chem, 264 : 16857-16962, 1989
(23) Jimi S, Smith TL, and Kummerow FA: 26-Hydroxycholesterol stimulated DNA synthesis in smooth muscle cells and induction of endothelial injury using a coculture technique. Biochem Med Meta Biol, 44: 114-125, 1990

(24) Ferrei LF : Fractionation of plasma lipoproteins: Evaluation of preparative methods. In : Story JA (ed) : Laboratory and research methods in biology and medicine. Vol. 10, New York: Alan R Liss Inc, pp 133-156, 1984

(25) Yagi K: Assay for serum lipid peroxide level and its clinical significance. In : Yagi K (ed) Lipid peroxide in biology and medicine. New York: Academic Press, pp 223-242, 1982

(26) Saslaw LD and Waravdekar VS : Preparation of malonaldehyde bis-bisulfite sodium salt. J Organic Chem, 22 : 843-844, 1957

(27) Wedster DF and Hervey W : A quantitative assay for collagen synthesis in microwell fibroblast culture. Anal Biochem, 96: 220-224, 1979

(28) Sykes B, Puddle B, Francis M, and Smith R; The estimation of collagens from human dermis by interrupted gel electrophoresis. Biochem Biophys Res Commun, 72 : $1472-1480,1976$

(29) Peterkofsky B, Chojkier M, and Bateman J : Determination of collagen synthesis in tissue and cell culture systems. In H Furthmeyr (ed.), Immunochemistry of extracellular matrix. vol. II applications, 1st ed., CRC press, pp 19-47, 1982

(30) Smith T, Toda T, and Kummerow FA: Plasma lipid peroxidation in hyperlipidemic chickens. Atherosclerosis, 57 : 119-122, 1985

(31) Rosenfeld ME, Palinski W, Yla-Herttuala S, Butler S, and Witztum $\mathrm{JL}$ : Distribution of oxidation specific lipid-protein abducts and apolipoprotein B in atherosclerotic lesions of varying severity from WHHL rabbits. Arteriosclerosis, 10 : 336-349, 1990

(32) Duff GL: Summary of part II, in symposium on atherosclerosis. National Academy of Science-National Research Councilpubl 338, pp 121-128, 1954 